\title{
ОРГАНІЗАЦІЯ ВІДНОВНОГО ЛІКУВАННЯ ХВОРИХ З ПАТОЛОГІЄЮ ШКІРИ ТА ПІДШКІРНОЇ КЛІТКОВИНИ В САНАТОРНИХ УМОВАХ
}

\author{
${ }^{1}$ Львівський національний медичний університет імені Данила Галицького, м. Львів, Україна

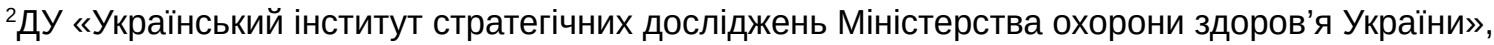 \\ м. Київ, Україна
}

\begin{abstract}
Мета: проаналізувати стан організації відновного лікування хворих із патологією шкіри та підшкірної клітковини в санаторних умовах.

Матеріали і методи. Вивчалися статистичні дані про кількість і контингент хворих, які перебували на лікуванні в ДП «Санаторій «Немирів» у 2006-2014 рр., у т.ч. за класом «Хвороби органів шкіри та підшкірної клітковини». Методи: бібліосемантичний, системного підходу, структурно-логічного аналізу, медичної статистики, інформаційний.

Результати. Протягом 2006-2014 рр. у санаторії пролікувалися 17858 пацієнтів, 3 них 18,79\% - хворі із захворюваннями шкіри та підшкірної клітковини; найчастішою патологією був псоріаз (49,87\%). У результаті проведеного лікування у всіх хворих, в т.ч. з патологією шкіри та підшкірної клітковини, відмічалося покращання стану, зменшилась кількість хворих з обмеженим самообслуговуванням, зросла здатність самостійно пересуватися.

Висновки. Відновне лікування на санаторному етапі сприяє підвищенню ефективності лікування та зниженню втрати працездатності. Відновне лікування в умовах санаторію дає можливість через прискорення процесу відновлення основних функцій шкіри покращити імунний захист організму, нормалізувати стан нервової системи, очистити організм, поліпшити загальний стан пацієнта, сприяти зросту його фрункцій життєдіяльності.
\end{abstract}

КЛЮчОВІ СлОВА: санаторій, патологія шкіри та підшкірної клітковини, відновне лікування.

Демографрічна криза, вражаючі показники смертності та захворюваності населення, особливо працездатного віку, швидке поширення неінфекційних захворювань сприяють скороченню чисельності громадян нашої країни [1;8;19]. Сучасний стан здоров'я населення вимагає негайного реформування галузі охорони здоров'я, у т.ч. удосконалення системи відновного лікування (ВЛ) після перенесених захворювань, оперативних втручань, хіміотерапевтичного лікування, а також 3 основним акцентом на вторинну профрілактику при хронічних захворюваннях [9;15].

Метою державної політики України $є$ ефеективне використання курортного потенціалу країни задля оздоровлення населення, збереження генофонду та відтворення трудових ресурсів [17;18]. В основу санаторно-курортної допомоги покладені найбільш гуманні, соціально та науково прогресивні принципи: профілактична і реабілітаційна спрямованість; послідовність, спадкоємність між амбулаторнодіагностичними, стаціонарними та санаторнокурортними закладами; висококваліфрікована спеціалізована допомога. На сьогодні потреба в санаторно-курортній допомозі досить значна. Водночас висока ефективність цього виду медичної допомоги щедро відшкодовує вкладені у неї коштів. Науковими дослідженнями та багаторічним практичним досвідом показано, що в результаті са(c) B.C. Комар, 2016 наторно-курортного лікування у 2-3 рази зменшується кількість загострень основного захворювання; хворі у 3-4 рази частіше та в 1,5-2,5 разу швидше повертаються до продуктивної праці; у 2-4 рази знижується рівень подальших працевтрат [6].

Прийнятий у 2000 році Закон України «Про курорти» визначив правові, організаційні, економічні та соціальні положення щодо розвитку курортів в Україні з метою повноцінного використання природних лікувальних ресурсів для оздоровлення населення, які в цілому відповідають нормам міжнародного права. Висока медико-соціальна значущість та економічна ефективність лікувальних, реабілітаційних та оздоровчо-профрілактичних заходів на санаторно-курортному етапі, недосконалість законодавчої бази та цілий ряд проблем нормативно-правового характеру, пов'язаних із забезпеченням практичної реалізації принципів ресрормування санаторно-курортної галузі, спонукають до розроблення документів, що регламентують діяльність санаторно-курортних закладів та комплексне застосування немедикаментозних лікувально-профрілактичних технологій $[7,13]$.

Мета дослідження: проаналізувати стан організації відновного лікування хворих у санаторних умовах, у т.ч. пацієнтів з патологією шкіри та підшкірної клітковини.

Матеріали і методи. Матеріалом дослідження слугували статистичні дані про кількість і контин- 
гент хворих, які перебували на лікуванні в ДП «Санаторій «Немирів» ПрАТ «Укрпрофроздоровниця» у 2006-2014 роках, у т.ч. за класом «Хвороби органів шкіри та підшкірної клітковини». Використано такі методи дослідження: бібліосемантичний, системного підходу і структурно-логічного аналізу, медичної статистики та інформаційний.

Результати дослідження та їх обговорення. Однією $з$ особливостей сучасного стану дерматології в Україні $€$ певний характер поширеності деяких захворювань шкіри, з якими пацієнти звертаються за медичною допомогою. Дані епідеміологічних характеристик окремих захворювань шкіри та підшкірної клітковини відіграють важливу роль у визначенні та побудові лікувальних алгоритмів [3;5;16].

В Україні в період з 1990 по 2013 роки рівень захворюваності на хвороби шкіри та підшкірної клітковини утримувався в межах 5-6\% від загальної захворюваності населення. 3 усіх класів за МКХ-10 клас «Хвороби шкіри та підшкірної клітковини» стабільно займає 4-5 рейтингове місце за величиною рівня захворюваності. В країні щодня реєструються понад п'ять нових випадків захворювання шкіри та підшкірної клітковини [2;4].

Лікування шкірної патології $€$ довготривалим комплексним процесом, який включає і санаторнокурортний етап. Об'єктивною необхідністю в реалізації Концепції Загальнодержавної цільової соціальної програми збереження і розвитку трудового потенціалу України на період до 2017 року [14] € розвиток і вдосконалення ВЛ у санаторнокурортних закладах. В Україні така допомога на санаторно-курортному етапі при патології шкіри та підшкірної клітковини надається переважно у санаторії «Немирів» (Львівська область), лікувально-діагностична база якого обладнана сучасною медичною апаратурою і дозволяє застосовувати новітні медичні технології та методики.

Санаторій створений у 1814 році. Розташований у великому лісовому масиві, серед якого розбитий лісопарк. Санаторій знаходиться на висоті 320 м над рівнем моря, з помірно-континентальним кліматом, що має сприятливий вплив на центральну нервову систему. Віддаленість від міст та промислового виробництва забезпечує чистоту повітря, що насичене озоном, мікроелементами, ефрірними оліями, фрітонцидами, дихати ними легко і вільно. Славу курорту принесла сірководнева вода, що застосовується близько 200 років і впливає як місцево на запальний процес, так і на основні фрункції організму - кровообіг, обмін речовин.

У санаторії фрунцціонують відділення для лікування хворих із захворюваннями кістково-м'язової системи, периферичної нервової системи, органів кровообігу та шкіри. Усього для хворих з патологією шкіри та підшкірної клітковини розгорнуто 70 ліжок.
Лікувальні процедури хворі із захворюваннями шкіри проходять на базі водоозокеритолікарні та лікувально-діагностичного корпусу санаторію. Показаннями для лікування хворих із патологією шкіри $\epsilon$ хронічна екзема без схильності до загострення, себорейне ураження шкіри, нейродерміти обмежені і дифузні, склеродермія, псоріаз (стаціонарна стадія, артропатичний псоріаз), червоний плоский лишай, іхтіоз, спадкові кератози, кератодермія, волосяний лишай, вітіліго, алопеція, кератодермія. Показаннями для лікування хворих з опіковою хворобою є: 1) опікові контрактури і дефрормації будьяких локалізацій, які розповсюджуються протягом перших 1,5 року після отримання опіків; 2) післяопікові рубці, які самостійно загоюються, ділянки опіків IIIA ступеня (протягом першого року після загоювання опікових ран); 3) достигаючі ділянки вільної пересадки шкіри (протягом першого року після пересадки шкіри); 4) гіпертрофрічні та келоїдні рубці після оперативного лікування (протягом перших 1,5 року після загоєння ран); 5) астенізація реконвалісцентів; 6) гіперкінез; 7) вегетотрофрічні порушення; 8) ураження перифреричних нервів; 9) опікова енцесралопатія.

За 2006-2014 роки в санаторії пролікувалось 17858 хворих, з них 3355 хворих з патологією шкіри та підшкірної клітковини, що складало 18,79\% (табл. 1). Щорічний відсоток цих пацієнтів від загального числа пролікованих не був постійним, що обумовлено різною кількістю путівок, виділених Фондом соціального страхування України, та кількістю самостійно придбаних пацієнтами.

У цей період із 3355 хворих із захворюваннями шкіри та підшкірної клітковини найбільший контингент пацієнтів був із псоріазом - 49,87\% (рис.).

Санаторно-курортна та реабілітаційна допомога надавалася згідно з рекомендованими стандартами санаторно-курортного лікування і діагностики, затвердженими МО3 України [11;12]. Випадків перебування в санаторії хворих без клінічних показань за звітний період не було.

Основою проведення лікувальних заходів у санаторії було: індивідуальний підхід з урахуванням соціального статусу, ступеня порушень життєдіяльності і працездатності хворого. Відновні заходи здійснюються з урахуванням усього комплексу фракторів: біологічних, особистісних, професійних і соціальних, відповідно до ролі і місця людини в оточуючому середовищі.

Провідними чинниками при лікуванні хвороб шкіри в санаторії є кліматотерапія (аеротерапія) та бальнеотерапевтичний - сірководневі купелі. При застосуванні ванн відмічається як неспецифічний, так і специфрічний вплив. Неспецифічний складається 3 температурного і механічного фракторів. У результаті рефлекторного подразнення шкіри відбуваються рефлекторні зміни в системі кровообігу та більш інтенсивно проходить обмін речовин. 
Таблиця 1. Кількість хворих, які перебували на лікуванні в санаторії «Немирів» у 2006-2014 роках, у т.ч. з патологією шкіри та підшкірної клітковини (абс.)

\begin{tabular}{|l|c|c|c|c|c|}
\hline Рік & $\begin{array}{c}\text { Усього } \\
\text { проліковано } \\
\text { хворих }\end{array}$ & $\begin{array}{c}\text { Усього хворих із } \\
\text { захворюванням } \\
\text { шкіри та підшкірної } \\
\text { клітковини }\end{array}$ & $\begin{array}{c}\text { Дерматит та } \\
\text { екзема }\end{array}$ & $\begin{array}{c}\text { Інші захворюван- } \\
\text { ня шкіри та } \\
\text { підшкірної } \\
\text { клітковини }\end{array}$ \\
\hline 1 & 2 & 3 & 4 & 5 & 6 \\
\hline 2006 & 2279 & 897 & 395 & 368 & 134 \\
\hline 2007 & 2081 & 267 & 79 & 137 & 51 \\
\hline 2009 & 2416 & 265 & 48 & 139 & 78 \\
\hline 2010 & 2080 & 222 & 69 & 77 & 51 \\
\hline 2011 & 2031 & 181 & 9 & 52 & 18 \\
\hline 2012 & 725 & 79 & 26 & 75 & 27 \\
\hline 2013 & 1660 & 128 & 235 & 397 & 127 \\
\hline 2014 & 2639 & 759 & 168 & 330 & 59 \\
\hline Разом & 1947 & 557 & 1061 & 1673 & 621 \\
\hline $2006-2014$ рр. & 17858 & 3355 & 5,94 & 9,37 & 3,48 \\
\hline
\end{tabular}

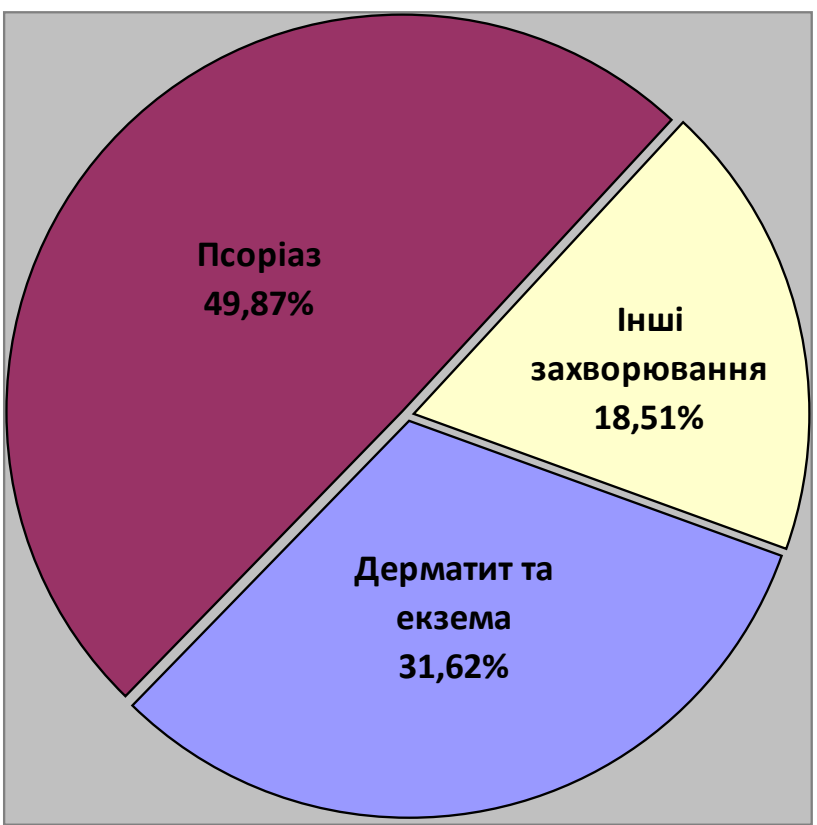

Рис. Розподіл пацієнтів з дерматологічною патологією за нозологіями (\%)

У результаті посилення кровообігу прискорюються відновні процеси у вогнищах патології, покращуються бар'єрні функкції організму. Тиск води викликає прискорене скорочення дихальних м'язів, здавлювання поверхневих судин шкіри, кров перерозподіляється у внутрішні органи, відбувається деяке підвищення артеріального тиску. Специфічний вплив на організм ванн 3 мінеральною водою пов'язаний з їх хімічним складом, вмістом біологічно активних речовин, які потрапляють у гуморальне русло і впливають на функцію органів та систем. Санаторій «Немирів» має сірководневу воду з концентрацією до 180 мг/л вільного сірководню (для купелей), яка у класифрікації мінеральних вод виділена у спеціальний «Немирівський» тип сірководневих вод. При купелях концентрація сірководню встановлюється залежно від характеру і динаміки процесу захворювання. Під час купелі сірководень проникає в організм людини через шкіру і слизову оболонку, а також через легені при диханні. Сірководневі купелі викликають почервоніння шкіри за рахунок розширення капілярів і припливу крові до шкіри з внутрішніх органів. Під впливом сірководню змінюється діяльність різних органів та систем: сповільнюється робота серця, знижується артеріальний тиск, покращується обмін речовин, зменшуються або зникають прояви різних запальних процесів (у шкірі, кістках, суглобах, хребцях, м'язах, сухожиллях, статевих органах), розширюються периферичні артерії та артерії серця, підвищується ріст волосся, зміцнюються міжхребцеві хрящові диски. Усе це сприяє профрілактиці і лікуванню хвороб шкіри, а також остеохондрозу хребта, ревматизму, гіпертонічної хвороби, атеросклерозу, хвороб статевих органів, нормалізації стану імунної і нервової систем. Пацієнти стають спокійними, у них покращується сон і настрій, вони рідше хворіють різними запальними процесами.

Сірководневі купелі зменшують активність утворення післяопікових колоїдних рубців, у результаті чого рубці згладжуються, стають більш м'якими, 
зменшується інтенсивність їх кольору, у них припиняються свербіж і болі, збільшується об'єм рухів у суглобах у випадку локалізації біля них рубців. Гіпертрофрічні і колоїдні рубці частково розсмоктуються, зникають неприємні відчуття у місці їх локалізації.

Досвід післяопікового реабілітаційного відділення санаторію показав, що своєчасне скерування хворих 3 післяопіковими рубцями, які самостійно заживають, дозріваючими ділянками шкіри, яка вільно пересаджена відразу після закінчення стаціонарного лікування, дає позитивні результати: зменшується висота рубця, підвищується його еластичність і рухомість, зменшується відчуття зростання м'яких тканин, зменшується свербіж у ділянці рубця і особливо важливо - здійснюється профрілактика утворення колоїдних рубців.

При значних опіках потрібно якомога швидше проводити реабілітаційне лікування для профрілактики контрактур та утворення колоїдних рубців.

Увагу сімейних лікарів, терапевтів, педіатрів треба звернути на те, що після опікової хвороби виникають різні зміни у внутрішніх органах: нейроциркуляторна дистонія, дистросрія міокарда, ерозивні ураження слизової шлунка і кишечника, а також розлади травлення, змінюється фрункці- ональний стан печінки, опікова енцефралопатія. Стан здоров'я хворих із перерахованою патологією значно покращується власне при лікуванні в санаторії «Немирів».

Визначення ефрективності санаторно-курортного лікування та реабілітації на санаторно-курортному етапі є недостатньо вивченим, воно здійснюється приблизно. Поза увагою дослідників залишаються медико-соціальні аспекти проблеми, з позицій комплексного підходу недостатньо опрацьовані медико-організаційні критерії ефрективності та прогнозу тривалості хвороби, у т.ч. визначення ефективності ВЛ з урахуванням психофізіологічного статусу пацієнта.

у 2010-2014 роках нами проведено оцінку обмеження життєдіяльності пацієнтів санаторію, яке було спричинене порушеннями стану здоров'я. При відборі чинників нами використано «Положення про порядок, умови та критерії встановлення інвалідності», яке затверджене Постановою Кабінету Міністрів України №1317 від 3 грудня 2009 р. [10]. Критерієм слугували наступні чинники: 1) здатність до самообслуговування; 2) здатність до самостійного пересування; 3) здатність до орієнтації; 4) здатність до спілкування; 5) здатність контролювати свою поведінку; 6) здатність до тру-

Таблиця 2. Зміна чинників життєдіяльності до і після ВЛ хворих у санаторії «Немирів» у 2010-2014 роках

\begin{tabular}{|c|c|c|c|c|c|}
\hline \multirow{2}{*}{$\begin{array}{c}\text { Основні чинники } \\
\text { оцінки життєдіяльності }\end{array}$} & \multicolumn{2}{|c|}{ Усього } & \multicolumn{2}{|c|}{ Р $>/<$} \\
\cline { 2 - 5 } & до ВЛ & після ВЛ & до ВЛ & після ВЛ & \\
\hline \multicolumn{7}{|c|}{ Обмежене самообслуговування } \\
\hline Усього & 282 & 194 & 100 & $68,79 \pm 2,76$ & $<0,01$ \\
\hline Усього & 209 & 123 & 100 & $58,85 \pm 3,40$ & $<0,01$ \\
\hline
\end{tabular}

дової діяльності (табл. 2). 3 перерахованих чинників здатність до орієнтації, здатність до спілкування, здатність контролювати свою поведінку, здатність до трудової діяльності та навчання була повною у всіх пацієнтів санаторію.

У результаті проведеного лікування в умовах санаторію у всіх хворих, у т.ч. з патологією шкіри та підшкірної клітковини, відмічалося покращання стану здоров'я. Кількість хворих із обмеженим самообслуговуванням зменшилась на $31,21 \pm 2,76 \%$ ( $<<0,01)$, у т.ч. зросла їх здатність до самообслуговування 3 використанням допоміжних засобів, за допомогою інших осіб, зменшилась залежність від інших осіб. Також зменшилась на 41,15ะ3,40\% $(p<0,01)$ кількість хворих з обмеженою здатністю до самостійного пересування, у т.ч. скоротився час на подолання відстані, рідше почали використовуватись допоміжні засоби та допомога інших людей.

Такий аналіз чинників ефективності санаторнокурортного лікування дозволяє оцінити стан жит- тєдіяльності хворих до та після ВЛ та встановити компенсаторно-адаптаційні можливості особи, реалізація яких сприяє медичній, професійній, трудовій, фрізичній, соціальній та психологічній реабілітації.

\section{Висновки}

Відновне лікування на санаторному етапі сприяє підвищенню ефрективності лікування та покращанню стану життєдіяльності хворих, що в свою чергу сприяє зниженню втрати працездатності.

Відновне лікування в умовах санаторію дає можливість через прискорення процесу відновлення основних функцій шкіри покращити імунний захист організму, нормалізувати стан нервової системи, очистити організм, поліпшити загальний стан пацієнта, сприяти зростанню його функцій життєдіяльності.

Перспективи подальших досліджень полягають у розробленні сучасної моделі підвищення якості та ефрективності лікування хворих із патологією шкіри та підшкірної клітковини. 


\section{Список літератури}

1. Аналіз демографрічної ситуації в Україні / Л. А. Чепелевська, В. Г. Дубініна, О. П. Рудницький, О. В. Любінець // щорічна доповідь про стан здоров'я населення, санітарно-епідемічну ситуацію та результати діяльності системи охорони здоров'я України. 2015 рік / за ред. Шафранського В. В.; МОЗ України, ДУ «УІСД МОЗ України». - Київ, 2016. - C. 12-33.

2. База медико-статистичної інформації «Здоров'я для всіх» Центру медичної статистики МОЗ України [Електронний pecypc]. - Режим доступу : http://medstat.gov.ua/ukr/news.html?id=203. - Назва з екрану.

3. Князевич В. М. Охорона здоров'я України: стан, проблеми, перспективи / В. М. Князевич [та ін.]. - Київ, 2009. $438 \mathrm{c.}$

4. Комар В. С. Патологія шкіри та підшкірної клітковини: динаміка захворюваності, поширеності і смертності в Україні / В. С. Комар, О. В. Любінець // Практична медицина. - 2012. - № 3. - С. 131-137.

5. Короленко В. В. Профресійні захворювання шкіри у працівників охорони здоров'я м. Києва / В. В. Короленко // Український журн. дерматол., венерол та косметол. - 2006. - № 3. - С. 15-19.

6. Костенко Г. П. Державне регулювання розвитку санаторно-курортних закладів / Г. П. Костенко // Вісник ДІтБ. - 2009. - № 13. - С. 70-74 (Серія «Економіка, організація та управління підприємствами туристичної індустрії та туристичної галузі в цілому»).

7. Лобода М. В. Забезпечення в Україні санаторно-курортної реабілітації на європейському рівні / М. В. Лобода, К. Д. Бабов, С. А. Доценко // Медична реабілітація, курортологія, фрізіотерапія. - 2006. - № 3 : Дод. : матеріали III нац. конгр. фрізіотерапевтів та курортологів «Медична реабілітація - сучасна система відновлення здоров'я». - С. 3-4.

8. Любінець О. В. Втрачений життєвий потенціал України у 2008 році / О. В. Любінець // Україна. Здоров'я нації. 2010. - № 3. - C. 32-38.

9. Пожидаєв В. В. Актуальні питання організації медичної реабілітації хворих на санаторно-курортному етапі / В. В. Пожидаєв, Л. І. Фісенко // Медична реабілітація, курортологія, фрізіотерапія : 2006. - № 3 : Дод. : матеріали III нац. конгр. фрізіотерапевтів та курортологів «Медична реабілітація - сучасна система відновлення здоров'я». C. 5-8.

10. Положення про порядок, умови та критерії встановлення інвалідності [Електронний ресурс]. - Шлях доступу : http://www.kmu.gov.ua/control/uk/cardnpd?docid=243200104.

11. Про затвердження клінічних протоколів санаторно-курортного лікування в санаторно-курортних закладах. (крім туберкульозного профрілю) для дорослого населення : наказ МОЗ України від 06.02.2008 № 56 [Електронний ресурс]. - Режим доступу : http://www.moz.gov.ua/ua/portal/dn_20080206_56.html. - Назва з екрану.

12. Про затвердження стандартів санаторно-курортного лікування дітей з соматичною патологією : наказ МО3 України від 12.05.2008 № 242 [Електронний ресурс]. - Режим доступу : http://www.moz.gov.ua/ua/portal/ dn_20080512_242.html. - Назва з екрану.

13. Про курорти : Закон України від 05.10.2000 № 2026-III [Електронний ресурс]. - Шлях доступу : http://zakon5.rada. gov.ua/laws/show/2026-14. - Назва з екрану.

14. Про схвалення Концепції загальнодержавної цільової соціальної програми збереження і розвитку трудового потенціалу України на період до 2017 року : розпорядження Кабінету Міністрів України від 22.06.2009 р. №851-р. // Офріційний вісник України. - 2009. - № 56. - С. 21-22.

15. Рижко П. П. До проблемних питань реформування галузі охорони здоров'я / П. П. Рижко // Дерматологія та венерологія. - 2011. - № 2 (52). - С. 26-31.

16. Степаненко В. І. Перспективи реформування системи охорони здоров'я в Україні, а також модернізація спеціалізованої медичної допомоги / В. І. Степаненко, П. П. Рижко // Вісник Харківського національного університету імені В. Н. Каразіна. - 2010. - Вип. 7 : Дод. : Сучасні проблеми дерматовенерології, косметології та управління охороною здоров'я : зб. наук. пр. - С. 3-19 (Серія «Медицина»).

17. Субота М. В. Організація та регулювання курортної діяльності в Україні / М. В. Субота // Економіка і управління. - 2014. - № 1. - С. 97-102.

18. Тарасенко О. І. Необхідність інноваційної політики в санаторно-курортній ссрері України / О. І. Тарасенко // Маркетинг інновацій і інновації у маркетингу : зб. тез доповідей VII Міжнародної наук.-практ. конфр., 26-28 вер. 2013 р. / відп. за вип. Ю. М. Гладенко. - Суми : ТОВ «ДД «Папірус», 2013. - С. 267-268.

19. Характеристика смертності населення України / О. М. Орда, О. В. Любінець, Ю. Б. Ященко, О. А. Семенюк // Інновації в медицині. - 2011. - № 7 (2). - С. 61-62.

\section{ОРГАНИЗАЦИЯ ВОССТАНОВИТЕЛЬНОГО ЛЕЧЕНИЯ БОЛЬНЫХ С ПАТОЛОГИЕЙ КОЖИ И ПОД- КОЖНОЙ КЛЕТЧАТКИ В САНАТОРНЫХ УСЛОВИЯХ \\ B.C. Комар ${ }^{1,2}$}

${ }^{1}$ Львовский национальный медицинский университет имени Данила Галицкого, г. Львов, Украина

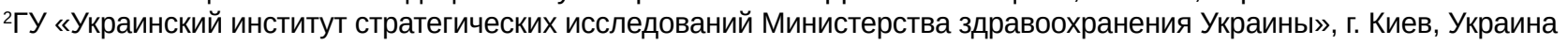

Цель: проанализировать состояние организации восстановительного лечения больных с патологией кожи и подкожной клетчатки в санаторных условиях.

Материалы и методы. Изучались статистические данные о количестве и контингенте больных, находившихся на лечении в ДП «Санаторий «Немиров» в 2006-2014 годах, в т.ч. по классу «Болезни органов 
кожи и подкожной клетчатки». Методы исследования: библиосемантический, системного похода, структурнологического анализа, медицинской статистики, информационный.

Результаты. В течение 2006-2014 гг. в санатории пролечились 17858 пациентов, из них 18,79\% больные с заболеваниями кожи и подкожной клетчатки; наиболее частой патологией был псориаз (49,87\%). В результате проведенного лечения у всех больных, в т.ч. с патологией кожи и подкожной клетчатки, отмечалось улучшение состояния, уменьшилось количество больных с ограниченным самообслуживанием, выросла способность самостоятельно передвигаться.

Выводы. Восстановительное лечение на санаторном этапе способствует повышению эффективности лечения и снижению потери работоспособности. Восстановительное лечение в условиях санатория дает возможность через ускорение процесса восстановления основных ффункций кожи улучшить иммунную защиту организма, нормализовать состояние нервной системы, очистить организм, улучшить общее состояние пациента, способствовать росту его функций жизнедеятельности.

КЛЮЧЕВЫЕ СЛОВА: санаторий, патология кожи и подкожной клетчатки, восстановительное лечение.

\section{THE ORGANIZATION OF REHABILITATION TREATMENT IN PATIENTS WITH DISEASES OF THE SKIN AND SUBCUTANEOUS TISSUE IN THE SANATORIUM CONDITIONS}

V.S. Komar, 1,2

${ }^{1}$ Danylo Halytskyi Lviv National Medical University, Lviv, Ukraine

${ }^{2} \mathrm{PE}$ „Ukrainian Institute of Strategic Researches MHC of Ukraine”, Kyiv, Ukraine

Objectives: to analyze the organization of rehabilitation treatment in patients with diseases of the skin and subcutaneous tissue in the sanatorium conditions.

Materials: patients who were treated at the state-owned enterprise «Nemyriv» Sanatorium» from 2006 to 2014, including the «Diseases of the Skin and Subcutaneous Tissue» class. Study methods: bibliography research and semantic methods, systematic approach, structural and logical analysis, medical statistical and information methods.

Findings. At the sanatorium over the period of 2006 to 201417.858 patients were treated, of which $18.79 \%-$ patients with diseases of the skin and subcutaneous tissue, the most common disease was psoriasis (49.87\%). As a result of the conducted treatment the improvement has been noted in all patients, including those with diseases of the skin and subcutaneous tissue, the number of patients with disability has been reduced, the ability to move independently has been increased.

Conclusions. Rehabilitation treatment at the sanatorium level improves the effectiveness of treatment and reduces disability. Via the accelerating process of main skin functions restoration, rehabilitation in the sanatorium conditions improves the immune defense of the body, brings back to normal the state of nervous system, cleanses the body, improves the patient's general state of health, promotes the development of his life functions.

KEY WORDS: sanatorium, diseases of the skin and subcutaneous tissue, rehabilitation treatment.

Рукопис надійшов до редакції 07.10.2016 р.

Відомості про автора:

Комар Володимир Степанович - асистент кафедри організації і управління охороною здоров'я Львівського національного медичного університету імені Данила Галицького. 